Research Paper

\title{
Impact of GAS5 genetic polymorphism on prostate cancer susceptibility and clinicopathologic characteristics
}

\author{
Chia-Yen Lin 1,2,3, Shian-Shiang Wang, 1,2,4, Cheng-Kuang Yang2, Jian-Ri Li1,2,5, Chuan-Shu Chen 1,2, \\ Sheng-Chun Hung, 1,2, Kun-Yuan Chiu ${ }^{2,4}$, Chen-Li Cheng1,2, Yen-Chuan Ou1,2,6, Shun-Fa Yang 1,7凶 \\ 1. Institute of Medicine, Chung Shan Medical University, Taichung, Taiwan \\ 2. Division of Urology, Department of Surgery, Taichung Veterans General Hospital, Taichung, Taiwan \\ 3. Division of Surgical Critical Care, Department of Critical Care Medicine, Taichung Veterans General Hospital, Taichung, Taiwan \\ 4. Department of Applied Chemistry, National Chi Nan University, Nantou, Taiwan \\ 5. Department of Medicine and Nursing, Hungkuang University, Taichung, Taiwan \\ 6. Department of Urology, Tung's Taichung MetroHarbor Hospital, Taichung, Taiwan \\ 7. Department of Medical Research, Chung Shan Medical University Hospital, Taichung, Taiwan \\ $\triangle$ Corresponding author: Shun-Fa Yang, PhD. Institute of Medicine, Chung Shan Medical University, 110, Section 1, Chien-Kuo N. Road, Taichung, Taiwan, \\ ROC. Fax: 886-4-24723229. E-mail: ysf@csmu.edu.tw
}

(C) The author(s). This is an open access article distributed under the terms of the Creative Commons Attribution License (https://creativecommons.org/licenses/by/4.0/). See http://ivyspring.com/terms for full terms and conditions.

Received: 2019.07.02; Accepted: 2019.08.09; Published: 2019.09.20

\begin{abstract}
Down-regulation of Growth arrest-specific 5 (GAS5) is correlated with enhanced cell proliferation and poorer prognosis of prostate cancer. We aimed to investigate the effect of variant rs 145204276 of GAS5 on the prostate cancer susceptibility and clinicopathologic characteristics. In this study, 579 prostate cancer patients who underwent robot-assisted radical prostatectomy and 579 healthy controls were included. The frequency of the allele del of rs 145204276 were compared between the patients and the controls to evaluate the impact of tumor susceptibility and the correlation of clinicopathological variables. The results shown that patients who carries genotype ins/del or del/del at SNP rs 145204276 showed decreased risk of pathological lymph node metastasis disease $(O R=0.545, p=0.043)$ and risk of seminal vesicle invasion $(O R=0.632, p=0.022)$ comparing to with genotype ins/ins. In the subgroup analysis of age, more significant risk reduction effects were noted over lymph node metastasis disease $(O R=0.426, p=0.032)$ and lymphovascular invasion $(O R=0.521$, $p=0.025$ ). In conclusion, the rs 145204276 polymorphic genotype of GAS5 can predict the risk of lymph node metastasis. This is the first study to report the correlation between GAS5 gene polymorphism and prostate cancer prognosis.
\end{abstract}

Key words: GAS5, prostate cancer, polymorphism, prognosis

\section{Introduction}

Prostate cancer (PCa) is one of the most prevalent malignancy in male gender at developed country. There are estimated 174650 newly diagnosed cases and 31620 cancer-related death in the United States alone in 2019 [1]. The incidence of PCa increases with advancing age. And $64 \%$ of new diagnosed cases were older than age 65 years [2]. Consider the relative limited life expectancy; the older patients are more likely to receive active surveillance and observation, instead of potentially curative local therapy.
However, the older patients were reported to get high-risk prostate cancer at diagnosis more frequently [3]. And age is also known as a risk factor of pathological upgrading to higher risk disease after radical prostatectomy [4]. The older men with high-risk disease, treated local therapy, had a $46 \%$ reduction of mortality risk comparing with who treated conservatively [3]. In current practice, the older $\mathrm{PCa}$ patients often received insufficient diagnostic survey and subsequent curative treatment 
[5]. In order to balance between cancer specific mortality and overtreatment of these older patients, further prognostic factors to identify who needed aggressive cancer treatment is an important issue.

In the past, the screening of prostate cancer was based on elevated prostate specific antigen (PSA) and digital examination. And we classified risk of $\mathrm{PCa}$ progression combining with tumor stage, PSA and Gleason score of tumor grading. However, there are numerous newly published evidences indicated the importance of genetic features (both genomic alteration and single nucleotide polymorphism) in PCa prediction and prognosis [6-9].

Recently, studies about tumor biology started focusing not only the coding sequence but also evaluating the impact of long noncoding RNAs (LncRNAs). LncRNAs defined as longer than 200 nucleotides and do not have ability to translate [10]. Although not in charge of protein coding, the LncRNAs can have regulatory effects of cell differentiation, migration, proliferation and apoptosis by interacting with DNA, RNA and proteins [11-13]. And genetic variant over the promoter region of LncRNA was reported to modulate the expression level by methylation [14].

Growth arrest-specific 5 (GAS5), a LncRNA encoded by the GAS5 gene, is recently identified as a tumor suppressor in several cancers such as lung, breast, prostate and colorectal cancers [15]. Although the exact expression level of GAS5 in PCa cell is still controversy, GAS5 is thought to play an important role in the proliferation, invasion, migration, and metastasis of PCa cells [16-18]. The expression of GAS5 was identified to downregulate microRNA-21(miR-21)/miR-1284, then increase the expression PTEN/ PCDC4/AKT and result in cell apoptosis and limit proliferation of prostate cancer cell [19].

Single nucleotide polymorphism (SNP) is defined as a single nucleotide from the shared genome sequence changed more than $1 \%$ within a population [20]. Several genetic polymorphisms had been associated with PCa risk, tumor grading and PCa specific mortality [21-23]. The variant rs145204276, shown as "-/AGGCA ", is a 5-bp indel polymorphism in the GAS5 promoter region. Rs145204276 was reported to affect expression of GAS5 and increase susceptibility of several cancers [24-26]. Moreover, this SNPs of GAS5 gene was reported significantly affecting the gleason score, disease stage and prognosis of prostate cancer [19]. But, there are only 158 PCa patients included in this study, and this sample size is a little below power to conclude the susceptibility of prostate cancer and SNP of GAS5. Our study design is to further test the effect of SNP rs145204276 of GAS5 in PCa patient. To our knowledge, this study has the biggest sample size to test correlation of the SNP of GAS5 and cancer susceptibility and clinicopathologic characteristics of PCa patients in Taiwan to date.

\section{Materials and Methods}

\section{Description of enrolled subjects}

In this study, we enrolled 579 patients with adenocarcinoma of prostate, underwent robotic assisted radical prostatectomy from 2012 to 2017 at Taichung Veteran General Hospital. At the same time, 579 age-matched individuals were also included as healthy control. Before opening of this study, the approval was certified by the Institutional Review Broad (IRB) of Taichung Veteran General Hospital, and the informed consent was written by each participant (IRB No. CE19062A). The medical information for each patient was acquired from personal medical records, including initial PSA level at diagnosis, Gleason score of initial biopsy, clinical and pathological TNM staging, Gleason grade group [27], D'Amico classification [28] and all the pathological features of permanent pathological result.

\section{Specimen collection and Genomic DNA extraction}

Whole blood samples were collected from controls and PCa patients. There were $579 \mathrm{PCa}$ patients included and all the blood sample were obtained before surgery. The specimens were placed in tubes with EDTA, centrifuged immediately then stored at $-80{ }^{\circ} \mathrm{C}$. Genomic DNA was extracted from whole blood sample with QIAamp DNA blood mini kits (Qiagen, Valencia, CA, USA) based on the manufacture's instruction as described previously [29]. DNA was dissolved with TE buffer and stored at $-20^{\circ} \mathrm{C}$ before Real-time PCR analysis.

\section{Selection of GAS5 genetic polymorphism}

The GAS5 variant rs145204276 is a 5-bp indel polymorphism located at the promoter region. Rs145204276 was selected in this study since this SNP was associated with the progression of several cancers [24-26]. The SNP rs145204276 of GAS5 was genotyped with TaqMan assay with SDS 3.0 software (Applied Biosystems, Foster City, CA, USA) and interpreted with StepOne ${ }^{\mathrm{TM}}$ Real-time PCR (RT-PCR) System (Applied Biosystems, Foster City, CA, USA).

\section{Statistical analysis}

A goodness-of-fit v2 test was used to exam Hardy-Weinberg equilibrium for biallelic markers. Mann-Whitney $U$ test were used to evaluate the 
differences among demographic characteristics between PCa group and controls. The odds ratios (ORs) with $95 \%$ confidence intervals (CIs) were calculated using logistic regression models to estimate the association between genotypic frequencies and different clinicopathological characteristics. The statistical significant difference was defined as $\mathrm{p}<0.05$. All the data were analyzed using Statistical Analytic System (SAS Institute, Cary, NC, USA) software (vers. 9.1, 2005) for Windows.

\section{Results}

\section{Characteristics of Study Participants}

The demographic characteristics in 579 patients were presented in this study (Table 1). At diagnosis, 334 patients $(57.7 \%)$ were older than 65 -year-old, 270 patients $(46.6 \%)$ had initial PSA level more than 10 $\mathrm{ng} / \mathrm{mL}, 501$ patients $(86.5 \%)$ were clinically localized disease $(\mathrm{cT} 1+\mathrm{cT} 2) .273$ and 49 patients had pathological proof locally advanced disease (pT3+pT4) (47.2\%) and lymph node metastasis (8.5\%) respectively. The percentages of low-, intermediate-, and high-risk PCa according to D'Amico classification were $10.4 \%$ (60), 38.0\% (220), and 51.6\% (299).

Table 1. The distributions of demographical characteristics in 579 patients with prostate cancer.

\begin{tabular}{ll}
\hline Variable & Patients (N=579) \\
\hline Age at diagnosis (years) & \\
$\leq 65$ & $245(42.3 \%)$ \\
$>65$ & $334(57.7 \%)$ \\
PSA at diagnosis (ng/mL) & \\
$\leq 10$ & $309(53.4 \%)$ \\
$>10$ & $270(46.6 \%)$ \\
Pathologic Gleason grade group & \\
$1+2+3$ & $484(83.6 \%)$ \\
$4+5$ & $95(16.4 \%)$ \\
Clinical T stage & \\
$1+2$ & $501(86.5 \%)$ \\
$3+4$ & $78(13.5 \%)$ \\
Pathologic T stage & \\
2 & $306(52.8 \%)$ \\
$3+4$ & $273(47.2 \%)$ \\
Pathologic N stage & \\
N0 & $530(91.5 \%)$ \\
N1 & $49(8.5 \%)$ \\
Seminal vesicle invasion & \\
No & $452(78.1 \%)$ \\
Yes & $127(21.9 \%)$ \\
Perineural invasion & \\
No & $155(26.8 \%)$ \\
Yes & $424(73.2 \%)$ \\
Lymphovascular invasion & \\
No & $482(83.2 \%)$ \\
Yes & $97(16.8 \%)$ \\
D'Amico classification & \\
Low risk & \\
Intermediate risk & $60(10.4 \%)$ \\
High risk & $220(38.0 \%)$ \\
\hline
\end{tabular}

Association of GAS5 gene polymorphisms and cancer susceptibility and clinical status of $\mathbf{P C a}$

The allele frequency of GAS5 rs145204276 SNP in the patients with $\mathrm{PCa}$ and non-cancer controls is shown in Table 2. In our recruited control group, the frequencies of GAS5 rs145204276 ( $\chi^{2}$ value: 0.132, $\mathrm{p}=0.717$ ) was in Hardy-Weinberg equilibrium. However, there are no significant correlations noted in all codominant/dominant/recessive/additive models. In the table 3, we evaluate the association of clinicopathologic characteristics of patients with $\mathrm{PCa}$ and GAS5 rs145204276 polymorphism. Patients who carries genotype ins/del or del/del showed decreased risk of pathological lymph node metastasis disease $(\mathrm{OR}=0.545 ; 95 \% \mathrm{CI}=0.301-0.988, \mathrm{p}=0.043)$ and risk of seminal vesicle invasion ( $\mathrm{OR}=0.632$; $95 \%$ $\mathrm{CI}=0.426-0.939, \mathrm{p}=0.022$ ) comparing to with genotype ins/ins. The risk of lymphovascular invasion is also slightly lower in patients who carry at least one del phenotype but there is no statistical significance (OR=0.647; 95\% CI=0.435-1.044, $\mathrm{p}=0.076)$. And no difference was noted in other well-known prognostic factors such as initial PSA level, pathological gleason grade group, clinical/pathological $\mathrm{T}$ stage and D'Amico risk classification.

Table 2. Associations between GAS5 rs145204276 and 579 patients with prostate cancer.

\begin{tabular}{|c|c|c|c|c|c|}
\hline $\begin{array}{l}\text { Genetic } \\
\text { model }\end{array}$ & Genotype & $\begin{array}{l}\text { Controls } \\
(\mathrm{N}=579) \mathrm{n} \\
(\%)\end{array}$ & $\begin{array}{l}\text { Patients } \\
(\mathrm{N}=579) \mathrm{n} \\
(\%)\end{array}$ & OR $(95 \%$ CI $)$ & p value \\
\hline \multirow{3}{*}{$\begin{array}{l}\text { Codominant } \\
\text { model }\end{array}$} & Ins/Ins & $237(40.9 \%)$ & $263(45.4 \%)$ & 1.000 & \\
\hline & Ins/Del & $270(46.7 \%)$ & $252(43.5 \%)$ & $\begin{array}{l}0.841 \\
(0.658-1.075)\end{array}$ & $p=0.167$ \\
\hline & Del/Del & $72(12.4 \%)$ & $64(11.1 \%)$ & $\begin{array}{l}0.801 \\
(0.548-1.171)\end{array}$ & $\mathrm{p}=0.252$ \\
\hline \multirow{2}{*}{$\begin{array}{l}\text { Dominant } \\
\text { model }\end{array}$} & Ins/Ins & $237(40.9 \%)$ & $263(45.4 \%)$ & 1.000 & \\
\hline & $\begin{array}{l}\text { Ins/Del + } \\
\text { Del/Del }\end{array}$ & $342(59.1 \%)$ & $316(54.6 \%)$ & $\begin{array}{l}0.833 \\
(0.660-1.051)\end{array}$ & $\mathrm{p}=0.123$ \\
\hline \multirow[t]{2}{*}{$\begin{array}{l}\text { Recessive } \\
\text { model }\end{array}$} & $\begin{array}{l}\text { Ins/Ins + } \\
\text { Ins/Del }\end{array}$ & $507(87.6 \%)$ & $515(88.9 \%)$ & 1.000 & \\
\hline & Del/Del & $72(12.4 \%)$ & $64(11.1 \%)$ & $\begin{array}{l}0.875 \\
(0.612-1.252)\end{array}$ & $\mathrm{p}=0.465$ \\
\hline \multirow{2}{*}{$\begin{array}{l}\text { Additive } \\
\text { model }\end{array}$} & Ins allele & $744(64.2 \%)$ & $778(67.2 \%)$ & 1.000 & \\
\hline & Del allele & $414(35.8 \%)$ & $380(32.8 \%)$ & $\begin{array}{l}0.878 \\
(0.739-1.042)\end{array}$ & $\mathrm{p}=0.137$ \\
\hline
\end{tabular}

The odds ratios (ORs) and with their $95 \%$ confidence intervals (CIs) were estimated by logistic regression models.

\section{Correlation of GAS5 SNPs and clinical status of $\mathrm{PCa}$ with age over $\mathbf{6 5}$ years}

In the table 4 , we evaluate the association of GAS5 rs145204276 polymorphism and clinicopathologic characteristics of patients with $\mathrm{PCa}$ and older than 65 years. Patients who carries GAS5 rs145204276 ins/del or del/del showed decreased risk 
of clinical locally advanced disease (OR $=0.513 ; 95 \%$ $\mathrm{CI}=0.286-0.923, \mathrm{p}=0.024)$, pathological lymph node metastasis disease $(\mathrm{OR}=0.462 ; 95 \% \mathrm{CI}=0.225-0.946$, $\mathrm{p}=0.032)$ and lymphovascular invasion $(\mathrm{OR}=0.521$; 95\% CI=0.292-0.927, $\mathrm{p}=0.025$ ) comparing to with genotype ins/ins. The risk of higher initial PSA level $(>10 \mathrm{ng} / \mathrm{mL}$ ) and seminal vesicle invasion are also slightly lower in patients who carry at least one del phenotype but there is no statistical significance (OR=0.676; 95\% CI=0.435-1.049, $\quad \mathrm{p}=0.080 ; \quad$ and $\mathrm{OR}=0.613 ; 95 \% \mathrm{CI}=0.370-1.018, \mathrm{p}=0.057$, respectively). And no difference was noted in other well-known prognostic factors such as pathological gleason grade group, pathological $\mathrm{T}$ stage and $\mathrm{D}^{\prime}$ Amico risk classification.

\section{Discussion}

Recently, increasing evidence indicated that decreasing expression of GAS5 can affect the susceptibility of many kinds of cancers and associated with poorer prognosis of hepatocellular carcinoma, cervical cancer, renal cancer, lung cancer, gastric cancer and melanoma [24-26, 30-32]. The rs145204276 ins/del polymorphism can regulate the expression of GAS5 through affecting one CpG island methylation condition [24]. Cancer patients with allele del of rs145204276 were also found to have remarkable higher expression of GAS5 in several different cancer tissues, and prostate cancer is one of them [19, 24-26, 33]. The del allele of rs145204276 was also significantly correlated with decrease risk of lung cancer, hepatocellular carcinoma and gastric cancer [24-26]. However, in our study, the del allele of rs145204276 did not affect the tumor susceptibility of prostate cancer. The result did not change when evaluating with codominant, dominant, recessive or additive model. The reason might be the risk of prostate cancer had already connected with numerous SNPs [34, 35]. Thus, the effect of GAS5 SNP about prostate cancer susceptibility became attenuated. To the best of our knowledge, this is the first study to evaluate the genetic polymorphism of GAS5 with susceptibility of prostate cancer.

In the analysis about clinicopathologic characteristics of prostate cancer in whole population, SNP rs145204276 was significantly associated with decreasing risk of pathological proved lymph node metastasis $(\mathrm{OR}=0.545 ; 95 \% \mathrm{CI}=0.301-0.988, \mathrm{p}=0.043$ ) and risk of seminal vesicle invasion $(\mathrm{OR}=0.632$; $95 \%$ $\mathrm{CI}=0.426-0.939, \mathrm{p}=0.022)$. There was also a better trend of decreasing lymphovascular invasion $(\mathrm{OR}=0.647$; 95\% CI=0.435-1.044, $\mathrm{p}=0.076)$. Lymphovascular invasion, also known as minimal lymphatic involvement, has been frequently reported as a prognostic factor to predict biochemical recurrence
(BCR) after radiotherapy and radical prostatectomy [36-39]. In the cause analysis of BCR, the increasing risk was mainly from progression to lymph node metastasis instead of residual tumor cells of positive surgical margins [39]. A recent study reported that the lymphovascular invasion of PCa cells has a significantly prognostic impact on disease progression.[40]

Table 3. Odds ratio (OR) and $95 \%$ confidence interval $(\mathrm{Cl})$ of clinical status and GAS5 rs 145204276 genotypic frequencies in 579 patients with prostate cancer.

\begin{tabular}{|c|c|c|c|c|}
\hline \multirow{2}{*}{$\begin{array}{l}\text { Variable } \\
\text { rs145204276 }\end{array}$} & \multicolumn{2}{|c|}{ Genotypic frequencies } & \multirow[b]{2}{*}{ OR $(95 \% \mathrm{CI})$} & \multirow[b]{2}{*}{ p value } \\
\hline & $\begin{array}{l}\text { ins/ins } \\
(N=263)\end{array}$ & $\begin{array}{l}\text { ins/del + } \\
\text { del/del } \\
(\mathrm{N}=316)\end{array}$ & & \\
\hline \multicolumn{5}{|l|}{$\begin{array}{l}\text { PSA at diagnosis } \\
(\mathrm{ng} / \mathrm{mL})\end{array}$} \\
\hline$\leq 10$ & $\begin{array}{l}148 \\
(56.3 \%)\end{array}$ & $161(50.9 \%)$ & 1.00 & $\mathrm{p}=0.201$ \\
\hline$>10$ & $\begin{array}{l}115 \\
(43.7 \%)\end{array}$ & $155(49.1 \%)$ & $\begin{array}{l}1.239 \\
(0.892-1.721)\end{array}$ & \\
\hline \multicolumn{5}{|c|}{$\begin{array}{l}\text { Pathologic Gleason } \\
\text { grade group }\end{array}$} \\
\hline $1+2+3$ & $\begin{array}{l}216 \\
(82.1 \%)\end{array}$ & $268(84.8 \%)$ & 1.00 & $\mathrm{p}=0.386$ \\
\hline $4+5$ & $47(17.9 \%)$ & $48(15.2 \%)$ & $\begin{array}{l}0.823 \\
(0.530-1.278)\end{array}$ & \\
\hline \multicolumn{5}{|l|}{ Clinical T stage } \\
\hline $1+2$ & $\begin{array}{l}223 \\
(84.8 \%)\end{array}$ & $278(88.0 \%)$ & 1.00 & $\mathrm{p}=0.264$ \\
\hline $3+4$ & $40(15.2 \%)$ & $38(12.0 \%)$ & $\begin{array}{l}0.762 \\
(0.473-1.229)\end{array}$ & \\
\hline \multicolumn{5}{|l|}{ Pathologic T stage } \\
\hline 2 & $\begin{array}{l}140 \\
(53.2 \%)\end{array}$ & $166(52.5 \%)$ & 1.00 & $\mathrm{p}=0.867$ \\
\hline $3+4$ & $\begin{array}{l}123 \\
(46.8 \%)\end{array}$ & $150(47.5 \%)$ & $\begin{array}{l}1.029 \\
(0.741-1.427)\end{array}$ & \\
\hline \multicolumn{5}{|l|}{ Pathologic N stage } \\
\hline No & $\begin{array}{l}234 \\
(89.0 \%)\end{array}$ & $296(93.7 \%)$ & 1.00 & $\mathrm{p}=0.043^{*}$ \\
\hline N1 & $29(11.0 \%)$ & $20(6.3 \%)$ & $\begin{array}{l}0.545 \\
(0.301-0.988)\end{array}$ & \\
\hline \multicolumn{5}{|l|}{$\begin{array}{l}\text { Seminal vesicle } \\
\text { invasion }\end{array}$} \\
\hline No & $\begin{array}{l}194 \\
(73.8 \%)\end{array}$ & $258(81.6 \%)$ & 1.00 & $\mathrm{p}=0.022^{*}$ \\
\hline Yes & $69(26.2 \%)$ & $58(18.4 \%)$ & $\begin{array}{l}0.632 \\
(0.426-0.939)\end{array}$ & \\
\hline \multicolumn{5}{|c|}{ Perineural invasion } \\
\hline No & $63(24.0 \%)$ & $92(29.1 \%)$ & 1.00 & $\mathrm{p}=0.163$ \\
\hline Yes & $\begin{array}{l}200 \\
(76.0 \%)\end{array}$ & $224(70.9 \%)$ & $\begin{array}{l}0.767 \\
(0.528-1.114)\end{array}$ & \\
\hline \multicolumn{5}{|l|}{$\begin{array}{l}\text { Lymphovascular } \\
\text { invasion }\end{array}$} \\
\hline No & $\begin{array}{l}211 \\
(80.2 \%)\end{array}$ & $271(85.8 \%)$ & 1.00 & $\mathrm{p}=0.076$ \\
\hline Yes & $52(19.8 \%)$ & $45(14.2 \%)$ & $\begin{array}{l}0.674 \\
(0.435-1.044)\end{array}$ & \\
\hline \multicolumn{5}{|c|}{$\mathrm{D}^{\prime}$ Amico classification } \\
\hline $\begin{array}{l}\text { Low risk/ } \\
\text { Intermediate risk }\end{array}$ & $\begin{array}{l}129 \\
(49.0 \%)\end{array}$ & $151(47.8 \%)$ & 1.00 & $p=0.762$ \\
\hline High risk & $\begin{array}{l}134 \\
(51.0 \%)\end{array}$ & $165(52.2 \%)$ & $\begin{array}{l}1.052 \\
(0.758-1.459)\end{array}$ & \\
\hline
\end{tabular}

The ORs with analyzed by their $95 \%$ CIs were estimated by logistic regression models. ${ }^{*} p$ value $<0.05$ as statistically significant. 
Table 4. Odds ratio (OR) and $95 \%$ confidence interval $(\mathrm{Cl})$ of clinical status and GAS5 rs 145204276 genotypic frequencies in 334 prostate cancer patients with age over 65 years.

\begin{tabular}{|c|c|c|c|c|}
\hline \multirow{2}{*}{$\begin{array}{l}\text { Variable } \\
\text { rs145204276 }\end{array}$} & \multicolumn{2}{|c|}{ Genotypic frequencies } & \multirow[b]{2}{*}{ OR $(95 \% \mathrm{CI})$} & \multirow[b]{2}{*}{ p value } \\
\hline & $\begin{array}{l}\text { ins/ins } \\
(\mathrm{N}=157)\end{array}$ & $\begin{array}{l}\text { ins/del + } \\
\text { del/del } \\
(\mathrm{N}=177)\end{array}$ & & \\
\hline \multicolumn{5}{|l|}{$\begin{array}{l}\text { PSA at diagnosis } \\
(\mathrm{ng} / \mathrm{mL})\end{array}$} \\
\hline$\leq 10$ & $57(36.3 \%)$ & $81(45.8 \%)$ & 1.00 & $\mathrm{p}=0.080$ \\
\hline$>10$ & $\begin{array}{l}100 \\
(63.7 \%)\end{array}$ & $96(54.2 \%)$ & $\begin{array}{l}0.676 \\
(0.435-1.049)\end{array}$ & \\
\hline \multicolumn{5}{|c|}{$\begin{array}{l}\text { Pathologic Gleason } \\
\text { grade group }\end{array}$} \\
\hline $1+2+3$ & $\begin{array}{l}122 \\
(77.7 \%)\end{array}$ & $146(82.5 \%)$ & 1.00 & $\mathrm{p}=0.274$ \\
\hline $4+5$ & $35(22.3 \%)$ & $31(17.5 \%)$ & $\begin{array}{l}0.740 \\
(0.431-1.270)\end{array}$ & \\
\hline \multicolumn{5}{|l|}{ Clinical T stage } \\
\hline $1+2$ & $\begin{array}{l}123 \\
(78.3 \%)\end{array}$ & $155(87.6 \%)$ & 1.00 & $\mathrm{p}=0.024^{*}$ \\
\hline $3+4$ & $34(21.7 \%)$ & $22(12.4 \%)$ & $\begin{array}{l}0.513 \\
(0.286-0.923)\end{array}$ & \\
\hline \multicolumn{5}{|l|}{ Pathologic T stage } \\
\hline 2 & $78(49.7 \%)$ & $91(51.4 \%)$ & 1.00 & $\mathrm{p}=0.752$ \\
\hline $3+4$ & $79(50.3 \%)$ & $86(48.6 \%)$ & $\begin{array}{l}0.933 \\
(0.607-1.434)\end{array}$ & \\
\hline \multicolumn{5}{|l|}{ Pathologic N stage } \\
\hline No & $\begin{array}{l}134 \\
(85.4 \%)\end{array}$ & $164(92.7 \%)$ & 1.00 & $\mathrm{p}=0.032^{*}$ \\
\hline $\mathrm{N} 1$ & $23(14.6 \%)$ & $13(7.3 \%)$ & $\begin{array}{l}0.462 \\
(0.225-0.946)\end{array}$ & \\
\hline \multicolumn{5}{|l|}{$\begin{array}{l}\text { Seminal vesicle } \\
\text { invasion }\end{array}$} \\
\hline No & $\begin{array}{l}112 \\
(71.3 \%)\end{array}$ & $142(80.2 \%)$ & 1.00 & $\mathrm{p}=0.057$ \\
\hline Yes & $45(28.7 \%)$ & $35(19.8 \%)$ & $\begin{array}{l}0.613 \\
(0.370-1.018)\end{array}$ & \\
\hline \multicolumn{5}{|c|}{ Perineural invasion } \\
\hline No & $33(21.0 \%)$ & $50(28.2 \%)$ & 1.00 & $p=0.127$ \\
\hline Yes & $\begin{array}{l}124 \\
(79.0 \%)\end{array}$ & $127(71.8 \%)$ & $\begin{array}{l}0.676 \\
(0.408-1.119)\end{array}$ & \\
\hline \multicolumn{5}{|l|}{$\begin{array}{l}\text { Lymphovascular } \\
\text { invasion }\end{array}$} \\
\hline No & $\begin{array}{l}122 \\
(77.7 \%)\end{array}$ & $154(87.0 \%)$ & 1.00 & $\mathrm{p}=0.025^{*}$ \\
\hline Yes & $35(22.3 \%)$ & $23(13.0 \%)$ & $\begin{array}{l}0.521 \\
(0.292-0.927)\end{array}$ & \\
\hline \multicolumn{5}{|c|}{$\mathrm{D}^{\prime}$ Amico classification } \\
\hline $\begin{array}{l}\text { Low risk/ } \\
\text { Intermediate risk }\end{array}$ & $62(39.5 \%)$ & $77(43.5 \%)$ & 1.00 & $\mathrm{p}=0.458$ \\
\hline High risk & $95(60.5 \%)$ & $100(56.5 \%)$ & $\begin{array}{l}0.848 \\
(0.548-1.312)\end{array}$ & \\
\hline
\end{tabular}

The ORs with analyzed by their $95 \%$ CIs were estimated by logistic regression models. ${ }^{*} \mathrm{p}$ value $<0.05$ as statistically significant.

Although we cannot provide the direct impact of SNP rs145204276 and the survival outcome, but considering the presence of lymph node metastasis after radical prostatectomy is a well-known poor prognostic factor with increased long-term risk of cancer specific mortality, estimated to range from $20 \%$ to $42 \%$ [41-43]. A worse cancer specific survival in patient with SNP rs145204276 might be a reasonable expectation, but further direct evidence to validate is still needed.

In the subgroup analysis of PCa patients with age classification, we realized the risk reduction effect of lymph node metastasis in patients with SNP rs145204276 is mainly contributed by the elders. PCa patients with age more than 65 year and carrying SNP rs145204276 are correlated to a $57.4 \%$ risk reduction of pathological proved lymph node metastasis $(\mathrm{OR}=0.426 ; 95 \% \mathrm{CI}=0.225-0.946, \mathrm{p}=0.032)$ and $47.9 \%$ risk reduction of lymphovascular invasion $(\mathrm{OR}=0.521$; $95 \% \mathrm{CI}=0.292-0.927, \mathrm{p}=0.025)$ significantly. And these risk reduction effects were not revealed in the age below or equal to 65 years' population.

In the current real world practice of $\mathrm{PCa}$ treatment, the older patients are more likely to receive active surveillance and observation, instead of potentially curative local therapy because of the relative limited life expectancy. However, the older patients were reported to have more aggressive prostate cancer at diagnosis more frequently [3]. And age is also considered as a risk factor of pathological upgrading to higher risk disease after operation[4]. In older men with high-risk disease, the aggressive treatment with a $46 \%$ reduction of mortality risk was reported comparing to treat conservatively [3]. To balance between survival benefit and overtreatment of these older patients, further prognostic factors to initiate or avoid aggressive cancer treatment is an important issue. And GAS5 SNP rs 145204276 could be part of the resolution. In our study, GAS5 SNP rs145204276 showed a strong prevention effect of lymphatic spreading in PCa patient older than 65 years. In the future study, the precise genetic mechanism with multifactorial evaluation of prostate cancer pathogenesis and prognosis is worthy for investigation.

In conclusion, although the GAS5 SNP rs145204276 did not affect the PCa susceptibility, our study indicated men with PCa and carrying GAS5 SNP rs145204276 are less likely to develop lymph node metastasis, especially in the age older than 65 years' group.

\section{Competing Interests}

The authors have declared that no competing interest exists.

\section{References}

[1] Siegel RL, Miller KD, Jemal A. Cancer statistics, 2019. CA Cancer J Clin 2019; 69: 7-34.

[2] Heinzer H, Steuber T. Prostate cancer in the elderly. Urol Oncol 2009; 27: 668-672.

[3] Bechis SK, Carroll PR, Cooperberg MR. Impact of age at diagnosis on prostate cancer treatment and survival. J Clin Oncol 2011; 29: 235-241.

[4] Druskin SC, Mamawala M, Tosoian JJ, Epstein JI, Pavlovich CP, Carter HB, et al. Older Age Predicts Biopsy and Radical Prostatectomy Grade Reclassification to Aggressive Prostate Cancer in Men on Active Surveillance. J Urol 2019; 201: 98-104.

[5] Pettersson A, Robinson D, Garmo H, Holmberg L, Stattin P. Age at diagnosis and prostate cancer treatment and prognosis: a population-based cohort study. Ann Oncol 2018; 29: 377-385. 
[6] Abida W, Cyrta J, Heller G, Prandi D, Armenia J, Coleman I, et al. Genomic correlates of clinical outcome in advanced prostate cancer. Proc Natl Acad Sci U S A 2019;

[7] Li-Sheng Chen S, Ching-Yuan Fann J, Sipeky C, Yang TK, Yueh-Hsia Chiu S, Ming-Fang Yen A, et al. Risk Prediction of Prostate Cancer with Single Nucleotide Polymorphisms and Prostate Specific Antigen. J Urol 2019; 201: 486-495.

[8] Chen WS, Aggarwal R, Zhang L, Zhao SG, Thomas GV, Beer TM, et al. Genomic Drivers of Poor Prognosis and Enzalutamide Resistance in Metastatic Castration-resistant Prostate Cancer. Eur Urol 2019;

[9] Lin CY, Wang SS, Yang CK, Li JR, Chen CS, Hung SC, et al. Genetic polymorphism and carbonic anhydrase 9 expression can predict nodal metastatic prostate cancer risk in patients with prostate-specific antigen levels $</=10 \mathrm{ng} / \mathrm{ml}$ at initial biopsy. Urol Oncol 2019;

[10] Su SC, Reiter RJ, Hsiao HY, Chung WH, Yang SF. Functional Interaction between Melatonin Signaling and Noncoding RNAs. Trends Endocrinol Metab 2018; 29: 435-445.

[11] Yao RW, Wang Y, Chen LL. Cellular functions of long noncoding RNAs. Nat Cell Biol 2019; 21: 542-551.

[12] Weng SL, Wu WJ, Hsiao YH, Yang SF, Hsu CF, Wang PH. Significant association of long non-coding RNAs HOTAIR genetic polymorphisms with cancer recurrence and patient survival in patients with uterine cervical cancer. Int J Med Sci 2018; 15: 1312-1319.

[13] Yang PJ, Hsieh MJ, Hung TW, Wang SS, Chen SC, Lee MC, et al. Effects of Long Noncoding RNA H19 Polymorphisms on Urothelial Cell Carcinoma Development. Int J Environ Res Public Health 2019; 16:

[14] Sasamoto H, Nagasaka T, Notohara K, Ozaki K, Isozaki H, Tanaka N, et al. Allele-specific methylation analysis on upstream promoter region of $\mathrm{H} 19$ by methylation-specific PCR with confronting two-pair primers. Int J Oncol 2004; 25: 1273-1278.

[15] Yu X, Li Z. Long non-coding RNA growth arrest-specific transcript 5 in tumor biology. Oncol Lett 2015; 10: 1953-1958.

[16] Luo G, Liu D, Huang C, Wang M, Xiao X, Zeng F, et al. LncRNA GAS5 Inhibits Cellular Proliferation by Targeting P27(Kip1). Mol Cancer Res 2017; 15: 789-799.

[17] Zhang Y, Su X, Kong Z, Fu F, Zhang P, Wang D, et al. An androgen reduced transcript of LncRNA GAS5 promoted prostate cancer proliferation. PLoS One 2017; 12: e0182305

[18] Petrovics G, Zhang W, Makarem M, Street JP, Connelly R, Sun L, et al. Elevated expression of PCGEM1, a prostate-specific gene with cell growth-promoting function, is associated with high-risk prostate cancer patients. Oncogene 2004; 23: 605-611.

[19] Zhu L, Zhu Q, Wen H, Huang X, Zheng G. Mutations in GAS5 affect the transformation from benign prostate proliferation to aggressive prostate cancer by affecting the transcription efficiency of GAS5. J Cell Physiol 2019; 234: 8928-8940.

[20] Su SC, Hsieh MJ, Lin CW, Chuang CY, Liu YF, Yeh CM, et al. Impact of HOTAIR Gene Polymorphism and Environmental Risk on Oral Cancer. J Dent Res 2018; 97: 717-724.

[21] Zheng SL, Sun J, Wiklund F, Smith S, Stattin P, Li G, et al. Cumulative association of five genetic variants with prostate cancer. N Engl J Med 2008; 358: 910-919.

[22] Loeb S, Carter HB, Walsh PC, Isaacs WB, Kettermann A, Tanaka T, et al. Single nucleotide polymorphisms and the likelihood of prostate cancer at a given prostate specific antigen level. J Urol 2009; 182: 101-104; discussion 105.

[23] Shui IM, Lindstrom S, Kibel AS, Berndt SI, Campa D, Gerke T, et al. Prostate cancer (PCa) risk variants and risk of fatal PCa in the National Cancer Institute Breast and Prostate Cancer Cohort Consortium. Eur Urol 2014; 65: 1069-1075.

[24] Tao R, Hu S, Wang S, Zhou X, Zhang Q, Wang C, et al. Association between indel polymorphism in the promoter region of lncRNA GAS5 and the risk of hepatocellular carcinoma. Carcinogenesis 2015; 36: 1136-1143.

[25] Li OJ, Ma G, Guo HM, Sun SH, Xu Y, Wang BJ. The Variant rs145204276 of GAS5 is Associated with the Development and Prognosis of Gastric Cancer. J Gastrointestin Liver Dis 2018; 27: 19-24.

[26] Li W, Huang K, Wen F, Cui G, Guo H, Zhao S. Genetic variation of IncRNA GAS5 contributes to the development of lung cancer. Oncotarget 2017; 8: 91025-91029.

[27] Epstein JI, Egevad L, Amin MB, Delahunt B, Srigley JR, Humphrey PA. The 2014 International Society of Urological Pathology (ISUP) Consensus Conference on Gleason Grading of Prostatic Carcinoma: Definition of Grading Patterns and Proposal for a New Grading System. Am J Surg Pathol 2016; 40: 244-252.

[28] D'Amico AV, Whittington R, Malkowicz SB, Schultz D, Blank K, Broderick GA, et al. Biochemical outcome after radical prostatectomy, external beam radiation therapy, or interstitial radiation therapy for clinically localized prostate cancer. Jama 1998; 280: 969-974.

[29] Hua KT, Liu YF, Hsu CL, Cheng TY, Yang CY, Chang JS, et al. 3'UTR polymorphisms of carbonic anhydrase IX determine the miR-34a targeting efficiency and prognosis of hepatocellular carcinoma. Sci Rep 2017; 7: 4466.

[30] Chen L, Yang H, Yi Z, Jiang L, Li Y, Han Q, et al. LncRNA GAS5 regulates redox balance and dysregulates the cell cycle and apoptosis in malignant melanoma cells. J Cancer Res Clin Oncol 2019; 145: 637-652.

[31] Yang W, Hong L, Xu X, Wang Q, Huang J, Jiang L. LncRNA GAS5 suppresses the tumorigenesis of cervical cancer by downregulating miR-196a and miR-205. Tumour Biol 2017; 39: 1010428317711315.
[32] Ji J, Dai X, Yeung SJ, He X. The role of long non-coding RNA GAS5 in cancers. Cancer Manag Res 2019; 11: 2729-2737.

[33] Lu S, Su Z, Fu W, Cui Z, Jiang X, Tai S. Altered expression of long non-coding RNA GAS5 in digestive tumors. Biosci Rep 2019; 39:

[34] Cheng I, Plummer SJ, Neslund-Dudas C, Klein EA, Casey G, Rybicki BA, et al. Prostate cancer susceptibility variants confer increased risk of disease progression. Cancer Epidemiol Biomarkers Prev 2010; 19: 2124-2132.

[35] Naylor SL. SNPs associated with prostate cancer risk and prognosis. Front Biosci 2007; 12: 4111-4131.

[36] Brooks JP, Albert PS, O'Connell J, McLeod DG, Poggi MM. Lymphovascular invasion in prostate cancer: prognostic significance in patients treated with radiotherapy after radical prostatectomy. Cancer 2006; 106: 1521-1526.

[37] Cheng L, Jones TD, Lin H, Eble JN, Zeng G, Carr MD, et al. Lymphovascular invasion is an independent prognostic factor in prostatic adenocarcinoma. J Urol 2005; 174: 2181-2185.

[38] Park YH, Kim Y, Yu H, Choi IY, Byun SS, Kwak C, et al. Is lymphovascular invasion a powerful predictor for biochemical recurrence in pT3 N0 prostate cancer? Results from the K-CaP database. Sci Rep 2016; 6: 25419.

[39] Kang YJ, Kim HS, Jang WS, Kwon JK, Yoon CY, Lee JY, et al. Impact of lymphovascular invasion on lymph node metastasis for patients undergoing radical prostatectomy with negative resection margin. BMC Cancer 2017; 17: 321

[40] Wilczak W, Wittmer C, Clauditz T, Minner S, Steurer S, Buscheck F, et al. Marked Prognostic Impact of Minimal Lymphatic Tumor Spread in Prostate Cancer. Eur Urol 2018; 74: 376-386.

[41] Abdollah F, Karnes RJ, Suardi N, Cozzarini C, Gandaglia G, Fossati N, et al. Impact of adjuvant radiotherapy on survival of patients with node-positive prostate cancer. J Clin Oncol 2014; 32: 3939-3947.

[42] Eggener SE, Scardino PT, Walsh PC, Han M, Partin AW, Trock BJ, et al. Predicting 15-year prostate cancer specific mortality after radical prostatectomy. J Urol 2011; 185: 869-875.

[43] Touijer KA, Karnes RJ, Passoni N, Sjoberg DD, Assel M, Fossati N, et al. Survival Outcomes of Men with Lymph Node-positive Prostate Cancer After Radical Prostatectomy: A Comparative Analysis of Different Postoperative Management Strategies. Eur Urol 2018; 73: 890-896. 